\title{
Palliative Care Workers: Demands and Stresses
}

\author{
Ami Rokach* \\ Department of Psychology, York University, Canada
}

Submission: March 06, 2017; Published: March 23, 2017

*Corresponding author: Ami Rokach, Department of Psychology, York University, Canada, Tel: 416-736-5125; Email: arokach@yorku.ca

\section{Abstract}

The article reviews the complex and demanding field of palliative care, noting the sources of the stresses and strains that the healthcare workers often encounter. It highlights the needs of patients, the reasons why they and/or their families may hamper palliative care

\section{Palliative Care}

The goal of palliative care is to offer the best quality of life for the dying, their families and support people, and to assist them to the many losses that they have endured. Palliative care aims to provide them with dignified treatment that will ease their departure from this life, and offer them a way of spending their last days in peace [1]. Palliative care provides "physical, emotional, spiritual and informational support to help improve the quality of a person's remaining life, and recognizes the patient and family as the principal decision makers" [2]. Palliative care utilizes its resources in order to make the dying patient as pain free and comfortable as possible, while it neither hastens nor postpones death. It offers a support system that enables and encourages patients to live as they can and wish until their dying day and supports their family and loved ones [3].

Palliative care is a stress filled, demanding, and complex profession

Let's examine the two major players who partake in palliative care: the patient and the careers.

\section{The patient}

The end-of-life experience encompasses feelings of hopelessness, death anxiety, guilt, and loneliness [4]. People who are ill and dying may pose particular demands for their careers. The dying patient may behave strangely, due to - for instance- brain tumors, cardiovascular diseases, or other illnesses. Psychological factors and psychiatric disorders may turn the patient into a demanding and difficult person to handle; examples of such factors are anger, mistrust, fear, or depression and paranoia which disrupts theirs and the lives of those close to them. The patient's symptoms may be so unpalatable to others so as to make them not want to visit or be with the patient, such as gross disfigurement, malodor, poor response to symptom management, or behavioral changes [5].

\section{What does a dying patient need?}

If we examine the needs of the patient, we can divide them into four categories:

Physical/medical needs such as pain management, the need to have a caring environment, and the patient's need to have at least some control over the situation.

Emotional/psychological needs - focusing on a search for meaning, and finding the courage to "let go" and bring closure to one's life. Social needs such as the need to love and be loved, to sustain trusting and intimate relations with those dear to the patient.

Spiritual/religious needs such as having hope and inner peace, and being able to participate in prayers [6].

\section{The Demands Put On Palliative Workers}

The palliative care worker is, frequently, faced with difficult patients and demanding or even unruly families who may not know how to cope with losing a loved one. The stresses that are heaved upon those careers include:

A. Breaking bad news to the family about the dying patient's diagnosis and/or prognosis.

B. Repeatedly evidencing the death of their patients, and experiencing the loss of someone that they may have formed relationships or just cared about them as people. 
C. Coping with the realization that medicine is unable to offer these people a cure.

D. As mentioned earlier, families may not know how to handle the situation and may dish out at the workers anger, grief, and despair.

E. Working within the medical system, one's personal belief system about the medical network, teamwork, death and dying may be shaken.

Remen [7] noted that "the expectation that we can be immersed in suffering and loss daily and not be touched by it, is as unrealistic as expecting to be able to walk through water without getting wet."

In contrast to physicians, nurses and other professional careers look after ill people whose condition generally improves, hospice workers are constantly in the presence of intense emotion, sadness, and impending death which highlights their inability to build up long term relationships with them $[8,9]$.

\section{Some Tips on Caring for the Careers}

Regardless of one's age, gender, profession or life stage - the palliative worker can succumb to the constant and unrelenting stresses and demands of their professional (on top of their personal) lives. Self-care, professional rejuvenation and social support are of prime importance, not only as a response to burnout, but better yet - as a way of preventing it. The self-care process needs to attend to, both, the personal and professional domains, by doing, at least some, of the following:

A. They must understand their strengths and weaknesses and once they can do it, they then can plan on how to live their personal and professional lives and how to use their strengths to compensate for their weaknesses.

B. Listen to their inner voice, be aware of their needs and yearnings, honor their intuition, and promote self-renewal.

C. Practice effective time management, set boundaries, and not expect themselves to behave as if they are perfect $[3,5,8,10]$.

D. Paying close and continuous attention to their relationships with those who support them. That includes developing and enhancing their social support network-our families.

E. Relaxation and centeredness, getting in touch with ourselves and our inner voice can be facilitated by relaxation and meditation.
F. Get, if needed, personal and professional support from colleagues or outside sources [11].

G. To summarize, in this article I have attempted to raise awareness of the loneliness experienced by the dying, and the stresses with which palliative workers are forced to endure. I have amassed, from a variety of sources, ways of preventing burnout but also of promoting what [12] described as the most desired stage in professional growth: deep compassion, where the "worker has the willingness and capacity to serve the dying, coupled with a feeling of his own worth that communicates comfort and respect to the dying person" (p. 106).

\section{References}

1. Tang ST, Mc Corkle R, Bradley EH (2004) Determinants of death in an inpatient hospice for terminally ill cancer patients. Palliat Support Care 2(4): 361-370.

2. van Bommel H (1992) Dying for care: Hospice care or euthenesia. NC Press, Toronto, Canada.

3. Faull C, Woof R (2002) Palliative care: An Oxford core text. Oxford University Press, NewYork, US.

4. Kuhl D (2011) Exploring the lived experience of having a terminal illness. J Palliat Care 27(1): 43-52.

5. Twycross $R$ (2003) Introducing palliative care. (4 $4^{\text {th }}$ edn), Radcliffe Medical Press, UK.

6. Rokach A, Rokach B (2005) The dying and the living: Caring for the patient and the professional who treats him/her. A paper presented at the $8^{\text {th }}$ annual conference of the Israeli Palliative Medicine Society, Tzfat, Israel.

7. Remen R (1996) Kitchen table wisdom. Riverhead books, New york, USA.

8. Robbins M (1998) Evaluating palliative care: Establishing the evidence base. Oxford University Press, Oxford, UK.

9. Chentsova-Dutton Y, Shucter S, Hutchin S, Strause L, Burns K, et.al (2002) Depression and grief reactions in hospice caregivers: From pre-death to 1 year afterwards. Journal of Affective Disorders 69(1-3): 53-60.

10. Oliviere D (2002) Learning in palliative care: Stories from and for my journey. In: C Mason (Ed.) Journey into palliative care: Roots and reflections. Jessica Kingsley Pub, London, UK, pp. 99-118.

11. Brems C (2000) Dealing with challenges in psychotherapy and counseling. Belmont CA Brooks/Cole.

12. Koff TH (1980) Hospice: A caring community. Winthrop Pubs, Cambridge, UK. 
(C) This work is licensed under Creative
Your next submission with Juniper Publishers will reach you the below assets

- Quality Editorial service

- Swift Peer Review

- Reprints availability

- E-prints Service

- Manuscript Podcast for convenient understanding

- Global attainment for your research

- Manuscript accessibility in different formats

( Pdf, E-pub, Full Text, Audio)

- Unceasing customer service

Track the below URL for one-step submission https://juniperpublishers.com/online-submission.php 